\title{
ЦЕРКОВЬ И АНТИКАТОЛИЧЕСКИЕ ДВИЖЕНИЯ В СРЕДНЕВЕКОВОЙ ЧЕХИИ: ОПЫТ ИССЛЕДОВАНИЙ УЧЁНЫМИ УКРАИНСКИХ ЗЕМЕЛЬ РОССИЙСКОЙ ИМПЕРИИ (ХІХ - НАЧАЛО ХХ В.)
}

\section{С. И. Лиман}

Лиман С. I. Церква та антикатолицькі рухи у середньовічній Чехії: досвід досліджень ученими українських земель Російської імперії (XIX - початок XX ст.). У статті розглядається вивчення вітчизняними богемістами (В. О. Більбасовим, А. С. Будиловичем, В. К. Надлером, О. О. Кочубинським, П. О. Лавровським) історії католицької Церкви й антикатолицьких рухів у середньовічній Чехії. Підкреслюється, що найбільших успіхів учені досягли, звертаючись до різних аспектів гуситського руху, боротьби чехів за релігійну, національну та політичну свободу у другій половині XV - на початку XVII ст., історії життя й діяльності канонізованих ієрархів чеської католицької Церкви. Домінуючі тенденції цих досліджень - слов'янофільські підходи авторів та визнання закономірності антикатолицьких рухів.

Ключові слова: Чехія; Церква; гусизм; історія; історіографія; Середні віки.

Лиман С. И. Церковь и антикатолические движения в средневековой Чехии: опыт исследований учёными украинских земель Российской империи (XIX - начало XX в.). В статье рассматривается изучение отечественными богемистами (В. А. Бильбасовым, А. С. Будиловичем, В. К. Надлером, А. А. Кочубинским, П. А. Лавровским и др.) истории католической Церкви и антикатолических движений в средневековой Чехии. Подчёркивается, что наибольших успехов учёные достигли, обращаясь к различным аспектам гуситского движения, борьбе чехов за религиозную, национальную и политическую свободу во второй половине XV - начале XVII вв., истории жизни и деятельности канонизированных иерархов чешской католической Церкви. Преобладающие тенденции данных исследований - славянофильские подходы авторов и признание закономерности антикатолических движений.

Ключевые слова: Чехия; Церковь; гусизм; история; историография; Средние века.

Liman S. I. Church and anti-catholic movements in the medieval Czech Kingdom: experience of research by scholars in Ukrainian lands of Russian Empire $\left(19^{\text {th }}-\right.$ early $2^{\text {th }}$ centuries $)$. The article discusses the study by Ukrainian Bohemia scholars (V. A. Bilbasov, A. S. Budylovich, V. K. Nadler, A. A. Kochubinskiy, P. A. Lavrovskiy et al.) of the history of Catholic Church and anti-catholic movements in the medieval Czech Kingdom. It is emphasized that most successful research took place in the study of various aspects of Hussite movement, struggle of Czechs for religious, national and political freedom in the second half of $15^{\text {th }}$ - beginning of $17^{\text {th }}$ centuries, history of life and deeds of sainted hierarchs of Czech Catholic Church. The predominant trends of this research were Slavophile approach by authors and recognition of substantiated character of anti-catholic movements.

Keywords: Czech Kingdom; Church; Hussism; history; historiography; Middle Ages.

Одним из приоритетных направлений исследований дореволюционных отечественных славистов традиционно являлась богемистика. Это было связано с той ролью, которую сыграла Чехия в Средние века в судьбах народов Центральной Европы, высоким уровнем развития ее экономики, образования, науки ${ }^{1}$. Пражский университет неизменно являлся главным научным центром, в который стремились наши слависты во время своих заграничных командировок, а личные контакты с представителями чешской исторической науки и знакомство с их научным наследием оказывали существенное влияние на трактовки в отечественных исследования ${ }^{2}$. Наконец, именно в чешской науке получили распространение столь популярные в России идеи панславизма, а история средневековой чешской Церкви, прежде всего гуситское движение, могли предоставить вполне адекватный исследовательский материал для подтверждения этих идейํ․

Крупными научными центрами подобных изучений в Российской империи стали высшие учебные заведения ее украинских земель - Харьковский университет, Университет Св. Владимира в Киеве, Новороссийский университет в Одессе, Киевская духовная академия, Историко-филологический институт князя Безбородко в Нежине. Комплексный 
анализ вклада учёных этих учебных заведений в изучение чешской средневековой церковной истории ещё не стал предметом специального историографического осмысления. К некоторым аспектам данной проблематики обращались при рассмотрении историографии гуситского движения ${ }^{4}$, деятельности реформаторов католической церкви ${ }^{5}$, научного наследия отдельных историков (В.А. Бильбасова ${ }^{6}$, А.С. Будиловича $\left.{ }^{7}\right)$, истории изучений в украинских землях Российской империи проблем средневековой Чехии ${ }^{8}$, истории славистики ${ }^{9}$ и медиевистики первого ${ }^{10}$ и второго ${ }^{11}$ этапов ее развития в дореволюционной Украине, славистики в Российской империи в целом ${ }^{12}$. В связи с этим цель статьи - на основе анализа всех работ историков высших учебных заведений украинских земель Российской империи выяснить их вклад в изучение истории средневековой чешской Церкви и антикатолических движений.

Данные изучения имели в украинских землях свои особенности. Львиная доля исследований харьковских, киевских, одесских учёных была посвящена именно антикатолическим движениям, в то время как публикации, посвящённые непосредственно истории чешской Церкви, были относительно редкими. В историографии справедливо отмечалось, что данная тематика удачно вписывалась в общероссийскую славянофильскую концепцию извечной борьбы германско-латинского и славянско-православного мира ${ }^{13}, \mathrm{a}$, например, гуситское движение было «главным сюжетом чешской феодальной истории» ${ }^{14}$. Интерес к другим сюжетам проявился позднее.

Среди ученых украинских земель Российской империи раньше всего в своих публикациях тему истории Чешской церкви и антикатолических движений затронули исследователи Харьковского университета. Первой опубликованной здесь работой, в которой содержался отдельный фрагмент истории гуситского движения, стал «Конспект, или краткое обозрение дипломатики вообще» (1829) харьковского профессора-юриста К.П. Пауловича (Павловича). Этот эпизод рассматривался в контексте описанных автором способов печатей, их количества, цвета, материала, а также языка, на котором писали средневековые дипломы. Указание было довольно лаконичным: «Богемцы в 1415 г. подали отцам Констанского собора прошение, утверждённое 350 печатями» ${ }^{15}$.

Впервые общую оценку деятельности чешских реформаторов католической Церкви дал харьковский медиевист М.М. Лунин в пробной лекции «Переход средней истории к новой и значение сей последней» (1835). Исследователь признавал закономерности зарождения учения Яна Гуса и Иеронима Пражского. «Богатство монастырей, праздная жизнь монахов уже рано развратили нравы и породили все пороки, - подчеркивал М.М. Лунин. - Гус умирает страдальческой смертью, но продолжительные войны гуситов служат уже сильным доказательством дальнейшего упадка власти Римских Первосвященников» ${ }^{16}$. К анализу гуситского движения обращался и ученик М.М. Лунина, выпускник Харьковского университета М.И. Сухомлинов. Уже в 1848 г. он подготовил кандидатское сочинение «О значеннии эпохи Гуса и его последователей в истории европейской цивилизации» ${ }^{17}$. Однако это сочинение не сохранилось.

Именно в середине XIX в. в отечественной богемистике и, в частности, в гуситологии зарождаются славянофильские концепции. Еще в 1848 г. в общероссийской историографии появилась написанная со славянофильских позиций рецензия В.А. Елагина на труд Ф. Палацкого «История Чехии» ${ }^{18}$. Первым же самостоятельным российским исследованием по истории гусизма следует считать состоящий из двух частей труд Е.П. Новикова «Гус и Лютер» $(1859)^{19}$.

В свою очередь, первой в украинских землях Российской империи научной монографией по истории гуситского движения стала магистерская диссертация харьковского историка В.К. Надлера «Причины и первые проявления оппозиции католицизму в Чехии и Западной Европе в конце XIV - начале XV в.» (1864). До появления монографии В.К. Надлера Е.П. Новиков усматривал в этом движении религиозную борьбу «между поклонниками Рима и защитниками грекославянских преданий» ${ }^{20}$, а А.Ф. Гильфердинг приписывал чехам намерения не только возвратиться в лоно православия, но и создать славянскую федерацию ${ }^{21}$. В.К. Надлер шире поставил вопрос о причинах гуситского движения. Он считал сопротивление католицизму в Чехии составным элементом общеевропейской религиозной оппозиции. Подчеркивая его не только конфессиональный, но и антинемецкий характер ${ }^{22}$, В.К. Надлер назвал немецкую колонизацию национальным бедствием для 
чехов. Именно этот тезис вызвал самое решительное возражение рецензента А.Н. Пыпина, который полагал, что «обнемечивание Чехии было добровольным делом со стороны чехов, а не военным насилием...» ${ }^{23}$.

В.К. Надлер довольно подробно охарактеризовал ереси в разных странах. Бесспорным достоинством работы являлась и та обстоятельность, с которой он осветил деятельность чешских предшественников Яна Гуса. В частности, автор максимально полно рассмотрел все известные произведения Матвея из Янова.

Значительное место В.К. Надлер уделил детальному сравнению учений Д. Виклефа и Я. Гуса и выяснению степени влияния английского реформатора католической Церкви на гуситское движение. Если некоторые отечественные авторы признавали факт огромного влияния на Гуса учения Виклефа ${ }^{24}$, то В.К. Надлер справедливо определил это влияние как второстепенный момент в гуситском движении ${ }^{25}$. Укажем, однако, что даже ближайший соратник Гуса, Иероним Пражский, в своём «Клятвенном отречении» заявлял о том, что проклинает «всякие ереси, особенно ту..., которой учили и которую защищали Джон Виклеф и Ян Гус» ${ }^{26}$. Из этих слов следует, что современники, как судьи, так и сам Иероним, считали учение Гуса и Виклефа по сути тождественным. В свою очередь Лаврентий из Бржезовой в одном случае писал «виклефисты, или гуситы», что означало для автора хроники их тождественность, в другом - «...против их (Виклефа и Гуса. - С. Л.) учений» $2^{27}$.

Несмотря на верное определение степени влияния Виклефа на Гуса, В.К. Надлер все же не сумел указать на другие причины - социальные, экономические, политические, которые, наряду с религиозными и национальными, вызвали гуситское движение*. Именно это обстоятельство и дало повод большинству историков, за исключением С.О. Никитина $^{31}$, отнести В.К. Надлера к славянофилам ${ }^{32}$.

О средневековой чешской Церкви и учении Яна Гуса писал и харьковский историк А.С. Лебедев. Если в публикации «Замечательные иностранные сочинения по истории славянства и его церковной жизни» (1869) он ограничился лишь пересказом содержания новых трудов, в том числе работы К. Гефлера «История гусизма», в которой тот осудил гуситское движение ${ }^{33}$, то в статье «Несколько слов о религиозном положении в Чехии» (1869) содержался краткий обзор А.С. Лебедевым истории христианства в чешских землях и учения Яна Гуса ${ }^{34}$. Поскольку «христианская вера в Чехии ведет свое начало от Св. Мефодия», чешский народ, как полагал ученый, несмотря на религиозные преследования немецкого духовенства «хранил память о своём первоначальном вероисповедании» ${ }^{35}$. Это мнение разделяли многие отечественные слависты ${ }^{36}$. «В лице Гуса, - далее подчеркивал А.С. Лебедев, - он (чешский народ - С. Л.) заявляет энергичный протест, который ... носит на себе ясные следы влияния начал восточного православия $»^{37}$. Это - классическая славянофильская трактовка, в целом характерная впоследствии и для его трехтомного труда «Церковная история» $(1902)^{38}$. Между тем сам Гус утверждал: «Я осуждал любостяжание и распутную жизнь священников, за что по милости Божией и терплю преследования» и «прошу вас жить по Закону Божию» ${ }^{39}$. А в «Прекрасной хронике» о Яне Жижке прямо говорится: Гус в проповедях «стал говорить против духовенства, начиная от наивысшего - папы, и кончая низшим священником, ... обличать их чванство, высокомерие, скупость, святокупство и разврат... $»^{40}$.

Ещё одной важной темой, имевшей непосредственное отношение к истории межконфессионального противостояния в Чехии и привлекающей внимание отечественных исследователей, стала история Чехии накануне и в начале Тридцатилетней войны. «Падением Чехии» традиционно называли это событие многие отечественные слависты. Не-

* Во многом это объяснимо содержанием источников. В важнейших из них - Кутногорском декрете, принятом Вацлавом IV в 1409 г., привилегии «немецкой нации» в Пражском университете передавались «чешской нации» «отныне на вечные времена» ${ }^{28}$. Однако то, что острота национального вопроса в Чехии преувеличивалась медиевистами Украины, свидетельствуют высказывания самого Яна Гуса. Даже во время следования на Констанский собор, он неоднократно писал в посланиях о том, как немцы разных областей принимали его «весьма дружелюбно», многие из них разделяли его взгляды. Ян Гус прибавлял при этом: «Должен признать, что нет ко мне нигде большей вражды, чем в среде жителей Чехии» ${ }^{29}$. Это же следует и из высказываний Лаврентия из Бржезовой ${ }^{30}$. 
случайно, что именно так - «Падение Чехии в XVII в.» (1863) - озаглавил свой очерк харьковский славист П.А. Лавровский.

Хронологически очерк охватывал время с 1516 по 1620 гг. - от смерти чешского короля Владислава до трагической для чехов битвы у Белой горы. Несмотря на то, что автор верно связал причину процветания Чехии при Максимилиане II и Рудольфе II прежде всего с их религиозной политикой веротерпимости, а также с расцветом науки и образования в стране, подходу П.А. Лавровского к изучаемой проблеме, в целом, свойственна абсолютизация национального фактора. Спорными представляются утверждения ученого о крепком национальном единстве чехов, изображенных носителями подлинной классовой гармонии. Следствием этой классовой гармонии в период до начала открытой католической реакции П.А. Лавровский считал быстрый рост материального благополучия чехов, которое доходило «даже до роскоши в самом низшем классе»" ${ }^{41}$. При этом автор категорически отказывался признать вклад в этот процесс немецко-католического населения Чехии. Эти славянофильские утверждения П.А. Лавровского должны были подтвердить его концепцию о решающей роли в судьбах Чехии борьбы славянского и германского духовных начал. Отметим, что автором откровенно замалчивался социальный характер розни в среде чешских протестантов, хотя едва ли можно считать преувеличенным описанный П.А. Лавровским религиозный фанатизм, с каким Фердинанд II повел борьбу против некатолического населения Чехии.

Изучение этой борьбы, разумеется, предполагало выяснение той социальной опоры, которая существовала у Фердинанда в чешских землях. Однако, по сути, замалчивая факт поддержки религиозной политики императора чехами-католиками, П.А. Лавровский склонен был усматривать в мерах Фердинанда и до, и после битвы у Белой Горы посягательства на весь чешский народ: «Не одна религия должна была вызывать самую ужасную мстительность Фердинанда и его советников, а и самое политическое устройство чехов, успевших возвысить свою народность до исключительного господства над иноземцами» ${ }^{42}$. Между тем, ещё Ф. Шиллер в своем известном историческом сочинении «Тридцатилетняя война» отмечал, что далеко не все чешские города поддержали восстание 1618 г., участников выступления судила чрезвычайная комиссия, в которой было немало «коренных чехов», а религиозным преследованиям в Чехии подверглись протестанты не только чешской, но и немецкой национальности ${ }^{43}$. Таким образом, нельзя не признать трактовку П.А. Лавровским причин, хода и последствий антикатолического и антигабсбургского восстания 1618 г. довольно ограниченной.

В последней четверти XIX - начале XX в. у славистов Харьковского университета почти пропадает интерес к истории Церкви и антикатолических движений в средневековой Чехии. Это было связано, главным образом, с кризисом славянофильской доктрины в отечественной богемистики вообще и гуситологии в частности. Новая позитивистская методология, занявшая в 1880-е годы основное место в отечественных исследованиях по славянскому Средневековью, способствовала постепенному пересмотру ряда откровенно устаревших взглядов на историю гусизма ${ }^{44}$. Среди них - отказ от изображения гуситского движения как попытки возврата чехов к православию ${ }^{45}$. Так, уже в 1880 г. в лекциях М.С. Дринова по истории западных славян говорилось: «Гуситское движение далеко не ограничивалось религиозными целями. К таборитам присоединился простой народ, которого интересовали как религиозные, так и социальные вопросы и который стремился к свободе, хотел уничтожить прежние общественные порядки» ${ }^{46}$.

С наибольшей полнотой изменение взглядов отечественных и, в частности, харьковских ученых на сущность исследуемого явления была отражена в статье С.М. Кульбакина «Петр Хельчицкий - чешский Толстой XV столетия» (1909). По его справедливому мнению, сущность гуситского движения не исчерпывалась только лишь религиозными и национальными факторами. Его важнейшей предпосылкой автор считал также противоречие между «старым феодально-крепостническим строем», который «в эту эпоху уже разлагался» и новой городской жизнью «с высоко развитыми формами промышленности и торговли» ${ }^{47}$. Всё это, по мысли С.М. Кульбакина, вело к «контрасту между бедностью и богатством», к углублению классовой розни. «Таким образом, - подчеркивал ученый, - из соединения моментов различного характера - религиозного, национального, социальноэкономического, культурного - сложилось широкое народное движение, известное под 
именем гуситского» ${ }^{48}$. Подобно В.К. Надлеру, С.М. Кульбакин считал выступление гуситов составным элементом общеевропейской оппозиции католицизму и выделял два лагеря в гуситском движении.

Схожие оценки в подходах к истории чешской Церкви и антикатолическим движениям демонстрировал и коллега С.М. Кульбакина, харьковский славист Г.А. Ильинский. В курсе «История славян» (1908) период «благоденствия» чешских земель он ограничивал двухсотлетием от смерти Гуса до Белогорской битвы ${ }^{49}$. Рассматривая предпосылки гуситского движения, Г.А. Ильинский приходит в целом к тем же выводам, что и В.К. Надлер. Подобно В.К. Надлеру, он считал Чехию лишь составным звеном общеевропейской оппозиции католицизму и указывал на влияние сочинений Виклефа на участников гуситского движения. Однако, гуситскую эпоху Г.А. Ильинский обозначал весьма широкими хронологическими рамками (1419-1526 гг.), а о самом гуситском движении в его курсе повествуется предельно кратко. Несмотря на это, ученому удалось выделить в среде гуситов два направления и указать главным образом не на антинемецкий, а на антифеодальный характер выступления чехов ${ }^{50}$.

В 1915 г. был опубликован первый в Российской империи «Краткий очерк истории славян» харьковского профессора А.Л. Погодина. В нем автор традиционно высоко оценивал гуситское движение, высказав при этом мысль о том, что «из гуситства чехи вышли, как чешский народ, уже навсегда обособившийся от германизма и сохранявший свое национальное сознание при самых неблагоприятных условиях» ${ }^{51}$. Несмотря на предельную краткость очерка, автор коснулся и вопроса о дальнейшем участии чехов в антикатолических движениях в Европе. Однако его оценки событий начального периода Тридцатилетней войны следует считать вполне традиционными для отечественной славистики. Подобно другим отечественным авторам, А.Л. Погодин считал поражение чехов у Белой Горы черным днем в истории Чешского государства и период, следующий за этой датой, предлагал целиком вписывать в историю Австрии ${ }^{52}$.

Вторым после Харьковского университета центром изучения в украинских землях Российской империи истории средневековой чешской церкви и антикатолических движений стал Университет Св. Владимира в Киеве. Первой публикацией, в которой содержалась оценка деятельности Яна Гуса, стало учебное пособие профессора кафедры всеобщей истории В.Я. Шульгина «Курс всеобщей истории. История средних векав» (1858). Хотя гуситское движение автор рассматривал в разделе «История Германии», а само это движение он называл одним из главных «явлений германской жизни» XIII-XV вв., в гусизме В.Я. Шульгин усматривал, прежде всего, национальные и религиозные причины. Категоричность некоторых антинемецких оценок автора доходит до того, что он, например, ошибочно заявлял, будто «все чехи из национального соперничества приняли его (Гуса С. Л.) сторону», а «новое учение стало делом народной чести» ${ }^{53}$. На оценки В.Я. Шульгина, скорее всего, повлияли не славянофильские доктрины, которые только зарождались, а концепции чешского историка Ф. Палацкого, считавшего, что «чешская история покоится, главным образом, на споре с немецким миром» и австрийского исследователя Й.А. Хельферта, который, хотя и осуждал само революционное движение гуситов, все же признавал закономерности этого движения (упадок католической Церкви, привилегированное положение немцев в Чехии и т.д. $)^{54}$. Нет в трактовке В.Я. Шульгина и обычных для славянофилов утверждений о попытках чехов вернуться в лоно православия. Наконец, в отличие от гуситологов-славянофилов, В.Я. Шульгин подчеркивал огромное влияние на формирование мировоззрения чешского реформатора учения английского богослова Д. Виклефа ${ }^{55}$.

Откровенно славянофильская точка зрения на суть учения Гуса выражена в сочинении выпускника Университета Св. Владимира А.К. Завадского-Краснопольского «Влияние греко-византийской культуры на развитие цивилизации в Европе» (1866). Та часть этого компилятивного сочинения, которая посвящена гуситскому учению, представляла собой почти сплошной цитатник из работ В.А. Елагина и Е.П. Новикова. Однако наряду с характерными для основоположников славянофильской гуситологии трактовками гуситского учения как результата «православно-византийского влияния» и стремления гуситов вернуться «к греко-византийской церкви» ${ }^{56}$. А.К. Завадский-Краснопольский отмечал огромное влияние на Гуса учения Виклефа. Между тем, факт этого влияния гуситологиславянофилы либо замалчивали, либо признавали со значительными оговорками. 
Главным образом источниковедческий аспект гуситской тематики исследовал киевский медиевист В.А. Бильбасов. В 1869 г. он опубликовал работу «Чех Ян Гус из Гусинца. Письма Яна Гуса, выбранные Мартином Лютером». 500-летний юбилей со дня рождения Гуса стал поводом для того, чтобы В.А. Бильбасов впервые на русском языке издал четыре предсмертные письма Гуса. И хотя введение к юбилейному изданию, написанное киевским ученым, компилятивно и неоднократно признавалось таковым как в дореволюционном $^{57}$, так и в современном славяноведении ${ }^{58}$, не оно, а научные комментарии к тексту писем Гуса могут и должны составить главный объект для изучения гуситологов.

Четыре письма Гуса, о которых идет речь, перевёл еще Лютер. В.А. Бильбасов опубликовал их параллельный текст - немецкий и русский. Эти письма Гус написал в Констанской тюрьме незадолго до своей казни. Нельзя не разделить естественного недоумения Л.П. Лаптевой, почему В.А. Бильбасов делал перевод не с чешского, а с немецкого языка, на который Лютер, в свою очередь, переводил письма с латинского ${ }^{59}$. «Мы не имеем под руками чешского подлинника», - объяснял это сам В.А. Бильбасов ${ }^{60}$. Однако в 1868 г., то есть за год до публикации самого В.А. Бильбасова, письма Гуса на языке оригинала опубликовал чешский исследователь Я. Эрбен. Подготовка к изданию у самого В.А. Бильбасова вряд ли заняла меньше года, и пренебрежение киевского ученого к научным зарубежным новинкам в данном случае исключается. Дискуссия о языке издания, с которого В.А. Бильбасов делал перевод, на наш взгляд, не может быть отнесена к числу первостепенных, поскольку многие свои работы Гус писал на латинском, а не на чешском языке, а указания на то, что эти письма были выбраны Лютером из раритетного издания немецкого реформатора, вообще снимают любые вопросы относительно того, почему киевский ученый не перевел эти письма с чешского подлинника.

Само указание на Лютера симптоматично: этим В.Я. Бильбасов фактически доказывал преемственность идеи реформы католической Церкви, а подчеркнутая мировоззренческая связь Гуса с Лютером, гусизма с лютеранством в данном случае не менее важна, чем подмеченная Л.П. Лаптевой славянофильская доктрина, в которую полностью вписывается одно из главных утверждений В.А. Бильбасова: «Эпоха реформаторского движения Чехии в XV столетии ... объясняется лишь присутствием православной стихии в историческом организме чешского народа ${ }^{61}$. Таким образом, В.А. Бильбасов-источниковед, а не историк гусизма, должен занимать своё место в гуситологии.

После рассмотренной выше публикации В.А. Бильбасова в Университете Св. Владимира изучением данной проблеме специально не занимались. Единственным обращением к этой теме стала рецензия, в которой киевский ученый Т.Д. Флоринский, в основном со славянофильских позиций, рассматривал сочинение австрийского историка, профессора Черновицкого университета И. Лозерта «Гус и Виклеф. О генезисе гуситского учения» (1884). Т.Д. Флоринский считал, что И. Лозерт, находясь под влиянием чешско-немецкого антагонизма, преувеличивал зависимость Гуса от Лютера и тенденциозно изображал полную несамостоятельность чешского реформатора. «Лозерт упустил из виду, что религиозная оппозиция латинству в Чехии еще в XIV в. отличалась национальным характером», - считал киевский ученый ${ }^{6}$. Тем самым Т.Д. Флоринский, по сути, повторил вывод А.Ф. Гильфердинга о стремлении Гуса и его последователей воссоздать в Церкви «то, что существовало в народе, как действительное предание минувшего» ${ }^{63}$.

К киевской школе богемистики и гуситологии принадлежали и исследования учёных Киевской духовной академии. Одним из наиболее полных по своему хронологическому охвату в отечественной гуситологии стал труд выпускника этой академии А.Ф. Вертеловского «История гуситов (до утверждения Базельских компактатов)» (1872-1873). Наряду с замеченными еще Л.П. Лаптевой заимствованиями А.Ф. Вертеловского у Е.П. Новикова и А.Ф. Гильфердинга ${ }^{64}$, подчеркнем, что не на них, а на Ф. Палацкого особенно часто ссылался автор. Именно высказывания Ф. Палацкого повлияли на многие выводы А.Ф. Вертеловского, в том числе о сходстве гусизма «с западным протестантизмом» ${ }^{65}$. При этом очевидно стремление автора показать социальный характер гусизма, наряду с религиозно-национальными причинами: «Западный протестантизм ... находил себе приверженцев особенно в высших классах. Гуситское движение ... не во всех классах ... находило себе одинаковое сочувствие: аристократия относилась к нему равнодушнее, чем массы простого народа» ${ }^{66}$. Это соответствует данным источников, в которых сам Гус 
среди своих врагов называет, прежде всего, «и епископов, и магистов, и светских князей, и законников» ${ }^{67}$.

Сочинение А.Ф. Вертеловского содержало в себе подробное изложение взглядов чешских реформаторов Милича, Матвея из Янова и самого Яна Гуса. Впервые в отечественной историографии, как отмечала еще Л.П. Лаптева, он привёл и полный текст отречения Иеронима Пражского на Базельском соборе, и два обвинительных акта против него. Среди проповедей Гуса автор выделял не только идею религиозного, но и «нравственного возрождения чешского народа», а о католической партии говорил не иначе, как о «католической чешской партии» ${ }^{68}$. Таким образом, автор подчеркивал ожесточенность борьбы внутри самих чехов, в частности, внутри гуситской партии, что отмечалось и в источниках ${ }^{69}$, а оценка причины поражения таборитов вполне вписывается в определение «давно существовавший раздор» ${ }^{70}$. Само окончание гуситского движения ученый датировал 1436 г. (Иглавским сеймом), в отличие от принятой ныне даты - 1434 г. (битва при Липанах), и встречающейся в чешской историографии даты - 1437 г. (падение Градец-Кралове) ${ }^{71}$.

Изучение истории чешской Церкви велось и в Новороссийском (Одесском) университете. Здесь эту тему рассматривал А.А. Кочубинский в монографии «Братья подобои и чешские католики в начале XVII в.» (1873). Об этом периоде автор писал, как о «последних свободных годах чешского народа», и даже называл «последним проявлением» чешской «исторической жизни» ${ }^{72}$. Так же данное событие изображалось и в общероссийской славистике ${ }^{73}$.

А.А. Кочубинскому удалось создать исследование, базирующееся на тщательной разработке широкого круга письменных источников ${ }^{74}$. К ним, прежде всего, относились пять отделений обширного сборника «Monumenta historiae bohemica». Они включали в себя декреты «братской общины», «Чешскую историю с 1602 по 1623 г.» П. Скалы из Загоры, «Воспоминания» В. Славаты, «дела утраквистской консистории» и т.д. На важность ряда этих источников указывал впоследствии Б.Н. Флоря ${ }^{75}$.

Общая концепция религиозной борьбы в Чехии, предложенная А.А. Кочубинским, в основном, отражала влияние официальной идеологии. В неё вполне удачно вписывалось утверждение автора о том, что с исчезновением Церкви Св. Кирилла и Мефодия на чешской земле «никогда не исчезала память о великих учителях посреди их первых, чешских учеников...» ${ }^{76}$. В этом контексте нельзя признать абсолютно бесспорным утверждение Л.П. Лаптевой о том, что «в отличие от историков-славянофилов К. (Кочубинский - С. Л.) не стремился доказать православный характер общины, видел влияние на неё западноевропейской реформации» ${ }^{77}$, хотя в дальнейшем та же Л.П. Лаптева указывала: А.А. Кочубинский «недооценивал .... влияния на Общину западноевропейской реформации» ${ }^{78}$. В действительности, А.А. Кочубинский в вопросе о влиянии на общину чешских братьев главную роль отводил Петру Хельчицкому. Влияние же западной Реформации едва ли можно считать доминирующим фактом, поскольку А.А. Кочубинский указывал: когда в 1522 г. община послала Лютеру на рассмотрение свое Исповедание веры, Лютер прервал всякие отношения с общиной ${ }^{79}$. Что касается чешского восстания 1547 г., то А.А. Кочубинский прямо называл его «легкомысленным», имевшим «самые несчастные последствия для благосостояния братской общины» ${ }^{80}$. Этот важный концептуальный вывод целиком соответствует данным источников. К примеру, один из организаторов восстания, Сикст из Оттерсдорфа в своей хронике прямо указывал на суровые репрессии против Братской общины после 1547 г., резкое ущемление свобод Чешского королевства и установление «тирании», при которой «в аду... и то лучше бывает» ${ }^{81}$.

A.А. Кочубинский считал Чехию второй половины XVI в. важнейшим звеном в цепи европейской контрреформации. Верным и аргументированным представляется и вывод А.А. Каченовского о достаточно прочной опоре у иезуитов внутри самой Чехии ${ }^{82}$.

Особое внимание он сосредоточил на изучении подготовки и решений исторического сейма 1609 г. При этом заседания сейма автор стремился фиксировать по дням. При анализе статей маестата учёный вскрыл противоречивость содержания этого документа, указав, в частности, на то, что уже вторая статья о консистории «не согласуется с первой», которой Рудольф «гарантирует свободу подобойского исповедания» ${ }^{83}$. Тем самым А.А. Кочубинский допускал в скором времени «возможность противникам религиозной свободы оспаривать их главнейшие положения» ${ }^{84}$. 
Главными виновниками попытки оспорить эти положения учёный считал новых правителей Чехии - Матвея и особенно Фердинанда II, чьи преследования некатоликов и «цензурные меры» привели к знаменитому восстанию 1618 г. Само восстание А.А. Кочубинский именовал не иначе, как «революцией», однако считал, что эта революция приготовила гибель Чешскому королевству ${ }^{85}$. Он выделял целый комплекс причин поражения чешских протестантов в 1620 г. Среди них, помимо внешнеполитических ошибок, - «сословный эгоизм, взаимное недоверие, рознь, мелкие счеты, безучастие массы, преобладание слова над делом» и т.д. ${ }^{86}$, а его выводы о том, что это восстание оказало огромное влияние на международные отношения, стали хрестоматийными и получили подтверждение в современной историографии ${ }^{87}$.

В Нежинском Историко-филологическом институте имени князя Безбородко историю средневековой чешской церкви изучал профессор А.С. Будилович. Характерные черты его исследований - их острый полемический характер, обличительная манера подачи материала. Указанные особенности проявились в его статье «О Яне Непомуцком, иезуитскогабсбургском святом» (1879) и в монографии «Очерки из церковной истории западных славян. Несколько критических замечаний на латинскую легенду о пражском епископе Войтехе» (1880). В них автор стремился не только развенчать заслуги указанных чешских католических иерархов, канонизированных Римом, но и высказать сомнения в объективности данных о них, содержащихся в средневековых летописях.

«Единственный подвиг» Яна Непомуцкого А.С. Будилович видел в том, что тот не открыл чешскому королю Вячеславу (Вацлаву IV) тайну исповеди его жены, королевы Иоанны, за что и был предан мученической смерти. «С точки зрения православной церкви священник, хранящий тайну исповеди, есть явление нормальное, - отмечал ученый. Только полная деморализация латинского духовенства, обратившего исповедь в средство политической и общественной пропаганды, с одной стороны, и в орудие семейного шпионства, с другой, могла составить тот тёмный фон, на котором образ охранителя исповедной тайны выделился бы в столь ослепительном блеске» ${ }^{88}$. А.С. Будилович провел тщательный анализ нарративных источников конца XIV в., в том числе Свитавской хроники и книг Пражской епископии. Этот анализ позволил ему поставить под сомнение сам факт казни в Праге Яна из Непомука в 1383 г., установленном его канонизаторами. «Высказываем убеждённость, что Ян Непомук есть подлог под Яна Гуса, - считал А.С. Будилович, - a с целью вытеснить память последнего из народной памяти было использовано сходство: имен, магистерской степени Пражского университета, духовного звания, наконец, насильственная смерть» ${ }^{89}$.

Свои исследовательские приемы, апробированные на католическом святом Яне Непомуцком, А.С. Будилович на более широкой основе применил вскоре в монографии «Очерки из церковной истории западных славян. Несколько критических замечаний на латинскую легенду о пражском епископе Войтехе». Основными источниками для него послужили два латинские жития Войтеха, написанные Яном Канапариусом и Бруноном.

Будучи последовательным славянофилом ученый рассматривал историю чешской Церкви Х в. и деятельность пражского епископа Войтеха исключительно в контексте борьбы восточно-православного и германо-римского начал. Приёмы критического исследования источников А.С. Будиловича свидетельствовали о его высочайшем профессионализме, как источниковеда. Он тщательно сопоставлял данные самых разных памятников по одному и тому же факту биографии Войтеха, что позволило ему пересмотреть некоторые ее вехи. Так, А.С. Будиловичу удалось установить более позднее, чем считалось, время рождения Войтеха $(958-960 \text { гг. })^{90}$. Основное содержание борьбы в чешской Церкви X в. А.С. Будилович усматривал не в столкновении христианства с язычеством, а в противоречиях внутри христианства между приверженцами двух его центров - «грекославянского и романогерманского» ${ }^{91}$. Именно в эту борьбу, которая «заняла весь $\mathrm{X}$ век и не вполне завершилась даже к концу XI века» ${ }^{92}$, предстояло вступить новоизбранному Пражскому епископу Войтеху.

Одна из главных задач А.С. Будиловича состояла в том, чтобы показать, как относился Войтех к проявлениям влияния восточной Церкви в Чехии и насколько преуспел в искоренении их. «О борьбе Войтеха с преданиями и обрядами славянской церкви в Чехии мы не находим ни одного свидетельства в латинских источниках», - указывал ученый ${ }^{93}$. В этом 
молчании католических авторов А.С. Будилович усматривал не отсутствие борьбы как таковой, а доказательство могущества противников католицизма и бесплодность деятельности Войтеха во главе Пражского епископства. И саму эту деятельность Войтеха, отмеченную «рабским служением идеям и целям латинонемецкой партии» ${ }^{94}$, и его миссионерство в Пруссии А.С. Будилович считал одинаково бесплодными по своим результатам. «Если же латинская церковь вознесла потом еп. Войтеха на пьедестал высоты недосягаемой, то это, - считал ученый, - объясняется не столько результатами, сколько направлением его деятельности, а равно и многими побочными целями латинской церкви» ${ }^{95}$. Вывод А.С. Будиловича о бесплодности деятельности Войтеха противоречил мнению Ф.И. Леонтовича, называвшего Войтеха «не политическим агитатором, а честным и искренним проповедником Христова учения $\rangle^{96}$, однако о перспективности проблемы чешско-германских церковных связей X-ХІ вв. свидетельствовали последующие работы В.Э. Регеля ${ }^{97}$

Отметим, что о реальных результатах миссионерства Войтеха в Пруссии ничего не сообщает нам хронист Галл Аноним, сочувственно описавший его гибель. По Галлу, Войтех мало чего добился и в Праге, поскольку был изгнан чехами ${ }^{98}$. Согласно другому хронисту, Козьме Пражскому, Войтех был очень «угоден императору своей службой», но по собственному желанию оставил пражскую кафедру из-за «беспутства народа» и «нерадения» духовенства, однако в Пруссии он всё же «посеял слово Божье» ${ }^{99}$.

Своими работами А.С. Будилович внёс основной вклад в изучение учёными Нежинского Историко-филологического института различных аспектов истории средневековой чешской церкви. Краткая публикация другого нежинского профессора М.Н. Сперанского «Гуситы и чешские братья» (1903) вошла в «Книгу для чтения по истории средних веков» и носила научно-популярный характер ${ }^{100}$.

В целом, исследователи украинских земель Российской империи внесли значительный вклад в изучение истории Церкви и антикатолических движений в средневековой Чехии. Центрами этих исследований были университеты Харькова, Киева, Одессы, Киевская духовная академия, Нежинский историко-филологический институт. Главными проблемами, которые вызвали постоянный, устойчивый интерес авторов, были: гуситское движение (В.К. Надлер, А.Ф. Вертеловский, В.А. Бильбасов), борьба чехов за религиозную, национальную и политическую свободу во второй половине XV - начале XVII вв. (П.А. Лавровский, А.А. Кочубинский), критика жизни и деятельности канонизированных иерархов чешской католической Церкви (А.С. Будилович). Характерной тенденцией подобных изучений следует считать признание указанными авторами закономерности антикатолических движений против злоупотреблений средневековой католической Церкви. Такой подход особенно проявился в работах по истории гусизма. Вместе с тем в большинстве исследований господствовала славянофильская точка зрения, в соответствии с которой борьба Яна Гуса и гуситское движение вообще являлись извечным стремлением чехов возвратиться в лоно православия и навсегда порвать с западным миром. Поражение антикатолического, антигабсбургского движения в Чехии в 1620 г. рассматривалось как национально-государственная катастрофа, навсегда подчинившая страну немецкому влиянию и католицизму. Кризис славянофильства в конце XIX в. обусловил падение интереса историков украинских земель Российской империи к рассматриваемой в данной статье тематике.

1 Лашнюков И.В. Состояние исторической науки у западных славян // Черниговский листок. 1863. - № 1. - С. 7; № 2. - С. 16.

${ }^{2}$ Багмут А.Й. Листування М.О. Максимовича і П.Й. Шафарика // Слов'янське мовознавство. 1961. - Вип. 3. - С. 285-286.

${ }^{3}$ Лавровский П.А. В воспоминание о Ганке и Шафарике // Акт в Харьковском университете 30 августа 1861. - Х., 1861.- С. 3.

4 Лаптева Л.П. Русская историография гуситского движения. - М.: Изд-во МГУ, 1978. - С. 61 $74,79-82$.

5 Лиман C.I. Реформатори католицької церкви XII-XV ст. в працях медієвістів України (18351885 рр.) // Науковий вісник Ужгородського Національного університету. - Сер.: Історія. - 2006. Вип. 17. - С. 145-151.

${ }^{6}$ Лиман C.I. Василь Олексійович Більбасов як історик-медієвіст: киівський період його науковопедагогічної діяльності (1867-1871рp.) // Вісник Харківської державної академії культури (далее - ВХДАК). - 2009. - Вип. 25. - С. 55-56. 
7 Лиман С.И. Из истории изучения средневековых славян: нежинский период научно-педагогической деятельности Антона Семёновича Будиловича (1875-1881) // Вісник Чернігівського державного педагогічного університету. - 2009. - Вип. 73. - Сер.: Історичні науки. - № 6. - С. 161-162.

${ }^{8}$ Лиман C.I. Середньовічна історія Чехії в працях учених українських земель Російської імперії (1804 - перша половина 1880-х рр.) // ВХДАК. - 2007. - Вип. 19. - С. 22, 24-30.

${ }^{9}$ Копилов С.А. Проблеми історії слов'янських народів в історичній думці України (остання третина XVII - початок XX ст.). - Кам'янець-Подільський: Оіюм, 2005. - С. 245-251.

${ }^{10}$ Лиман С.И. Идеи в латах: Запад или Восток? Средневековье в оценках медиевистов Украины (1804 - первая половина 1880-х гг.). - Х.: ХГАК, 2009. - С. 367-381.

${ }^{11}$ Лиман C.I. Медієвістика в Україні в кінці XIX - на початку XX ст. (1880-1917): дис...канд. іст. наук. - Х.: ХДУ, 1993. - С. 157-158.

12 Славяноведение в дореволюционной России: Биобиблиографический словарь. - М.: Наука, 1979. - С. 71-72, 99-100, 195-197, 212-213, 247-248; Славяноведение в дореволюционной России. Изучение южных и западных славян. - М.: Наука, 1988. - С. 236, 238; Лаптева Л.П. История славяноведения в России в ХІХ в. - М.: Индрик, 2005. - С. 120, 292, 293, 450, 451.

13 Лаптева Л.П. История славяноведения в России в ХІХ в. - С. 120. 235 .

${ }^{14}$ Славяноведение в дореволюционной России. Изучение южных и западных славян.... - С. 144,

${ }^{15}$ Паулович К.П. Конспект, или краткое обозрение дипломатики вообще. - Х.: Тип. ун-та, 1829. - C. 51 .

${ }^{16}$ Лунин М.М. Переход средней истории к новой и значение сей последней // Журнал Министерства народного просвещения (далее - ЖМНП). - 1835. - № 7. - С. 459-460.

${ }_{17}$ Славяноведение в дореволюционной России: Биобиблиографический словарь.... - С. 326.

${ }^{18}$ Елагин B.A. Об “Истории Чехии” Франца Палацкого // Чтения в Обществе истории и древностей российских. - 1848. - № 7. - С. 1-44.

${ }^{19}$ Новиков Е. Гус и Лютер. - М.: Тип. А. Семета, 1859. - Ч. 1. - 228 с.

${ }^{20}$ Там же-C. 1.

${ }^{21}$ Гильфердинг А. Собрание сочинений. - СПб.: Тип. В. Головина, 1868. - Т. 1. - С. 347.

${ }^{22}$ Надлер B.K. Причины и первые проявления оппозиции католицизму в Чехии и Западной Европе в конце XIV и начале XV в. - Х.: Тип. Ун-та, 1864. - С. 145.

${ }_{23}^{23}$ Пыпин А.Н. Рец. на: Надлер В.К. Причины и первые проявления оппозиции католицизму в Чехии и Западной Европе в конце XIV - начале XV в. - Харьков: Тип. ун-та, 1864 // Современник. 1864. - Т. 103. - Отд. 2. - № 7. - С. 45.

${ }^{24}$ Шульгин В.Я. Курс всеобщей истории для воспитанниц благородных институтов и воспитанников гимназий. История средних веков. - К.: Тип. ун-та, 1858. - С. 162.

${ }^{25}$ Надлер B.K. Причины и первые проявления оппозиции католицизму в Чехии и Западной Европе... - С. 225.

${ }^{26}$ Петр из Младоневиц. Повествование о магистре Иерониме Пражском, сожжённом в Констанце во имя Христа // Гуситское движение в освещении современников / Сост. и пер. проф. Л.П. Лаптева. - М., 1992. - III. - С. 65.

27 Лаврентий из Бржезовой. Гуситская хроника / Пер. А.С. Соколова, предисл. и примеч. Й. Мацека. - М.: Изд-во АН СССР, 1962. - V. - С. 27; Х. - С. 35.

${ }^{28}$ Кутногорский декрет (18 января 1409 г.) // Документы по истории университетов Европы XIIXV вв. / Вступ. ст., пер. и примеч. Г.И. Липатниковой. - Воронеж, 1973. - С. 65-66.

${ }^{29}$ Петр из Младоневиц. Донесение о магистре Яне Гусе в Констанце // Гуситское движение в освещении современников / Сост. и пер. проф. Л.П. Лаптева. - М., 1992. - Ч. 1. 1, III. - С. $21,27$.

30 Лаврентий из Бржезовой. Гуситская хроника....- II. - С. 22.

${ }^{31}$ Очерки истории исторической науки в СССР. - М.: Изд-во АН СССР, 1961. - Т. 2. - С. 504.

${ }^{32}$ Славяноведение в дореволюционной России: Биобиблиографический словарь... - С. 247; Лanтева Л.П. История славяноведения в России в ХІХ в. ... - С. 450.

33 Лебедев А.С. Замечательные иностранные сочинения по истории славянства и его церковной жизни. - М.: Тип. ун-та, 1869. - С. 6-14.

${ }^{34}$ Лебедев А.С. Несколько слов о религиозном положении Чехии // Православное обозрение (далее - ПО). - 1869. - Первое полугодие (май). - С. 250-258.

${ }^{35}$ Там же. - С. 250.

${ }^{36}$ Иванцุов-Платонов А. Очерк истории христианства у славянских народов // ПО. - 1869. - Первое полугодие. - С. 664.

37 Лебедев А.С. Несколько слов о религиозном положении Чехии... - С. 250.

${ }^{38}$ См.: Лебедев А.С. Церковная история: в 3 т. - Х.: Типо-Лит. С. Иванченко, 1902. - Т. 3. - 308 с.

${ }^{39}$ Петр из Младоневиц. Донесение о магистре Яне Гусе в Констанце... - I. 2. - С. 17; I. 4. - С. 28.

40 Прекрасная хроника о Яне Жижке // Гуситское движение в освещении современников / Сост. и пер. проф. Л.П. Лаптева. - М., 1992. - С. 74. 
${ }^{41}$ Лавровский П.А. Падение Чехии в XVII веке // ЖМНП. - 1863. - № 5. - С. 28.

${ }^{42}$ Там же. - C. 44.

${ }^{43}$ Шиллер Ф. Сочинения / Пер. с нем. под общ. ред. Н.Н. Вильмонта и Р.М. Самарина. - М.: Госиздат худ. литературы, 1957. - Т. 5. - С. 71, 89-90.

${ }^{44}$ Лаптева Л.П. К вопросу об основных этапах развития отечественного славяноведения (18351985) // Вопросы историографии и истории зарубежных славянских народов. - М., 1987. - С. 11.

${ }^{45}$ Историография истории южных и западных славян. - М.: Изд-во МГУ, 1987. - С. 184.

${ }^{46}$ Цит. по: Горина Л.В. Марин Дринов - историк и общественный деятель. - М.: Изд-во МГУ, 1986. - C. 115.

${ }^{47}$ Кульбакин С.М. Петр Хельчицкий - чешский Толстой XV столетия // Вестник Европы. - 1909.

- Т. 6. - Кн. 2. - С. 53.

${ }^{48}$ Там же. - С. 54.

${ }^{49}$ Ильинский Г.А. История славян. - Часть 1. История западных славян. - Х., 1908. - С. 20.

${ }^{50}$ Там же. - С. 263-264, 268.

${ }^{51}$ Погодин А.Л. Краткий очерк истории славян. - М.: Изд. Г.А. Лемана, 1915. - С. 72.

${ }_{52}^{5}$ Там же. - С. 80.

${ }_{53}$ Шульгин В.Я. Курс всеобщей истории. История средних веков. - К.: Тип. университета, 1858. - C. 162.

${ }^{54}$ См. подр.: Галямичев А.Н. Гуситское движение в освещении либеральной немецкой медиевистики второй половины XIX в. - Саратов: Изд-во Саратовского ун-та, 1988. - С. 16, 21-23.

${ }^{55}$ Шульгин В.Я. Курс всеобщей истории... - С. 162.

56 Завадский-Краснопольский А. Влияние греко-византийской культуры на развитие цивилизации в Европе. - К.: Тип. ун-та, 1866. - С. 108-110.

${ }^{57}$ См.: Будилович А.С. Рец. на: Бильбасов В.А. Чех Ян Гус из Гусинца. Письма Яна Гуса, выбранные Мартином Лютером. - СПб.: Печатня В. Головина, 1869. - XСІІ, 89 с. // ЖМНП. - 1869. - № 5. - C. 434-436.

${ }_{58}^{58}$ Копилов С.А. Проблеми історії слов'янських народів в історичній думці України... - С. 247.

59 Лаптева Л.П. Русская историография гуситского движения.... - С. 72.

${ }^{60}$ Бильбасов В.А. Чех Ян Гус из Гусинца. Письма Яна Гуса, выбранные Мартином Лютером. -

СПб.: Печатня В. Головина, 1869. - С. 84.

${ }_{61}$ Там же. - C. II.

${ }^{62}$ Флоринский Т.Д. По поводу сочинения И. Лозерта «Гус и Виклеф». [Рец. на: Loserth J. Hus und Wiclif. Zur Genesis der husistischen Lehre. - Prag: F. Lemski. - Leipzig: G. Freytag, 1884. - 314 s.] // Университетские известия. - 1884. - № 5. - С. 113.

${ }^{63}$ Гильфердинг А. Собрание сочинений. - СПб.: Тип. В. Головина, 1868. - Т. 1. - С. 358.

${ }^{64}$ Лаптева Л.П. Русская историография гуситского движения... - С. 80-81.

${ }_{65}^{65}$ Вертеловский А. История гуситов (до утверждения Базельских компактатов) // Труды Киевской духовной академии (далее - ТКДА). - 1872. - № 9. - С. 76.

${ }_{66}$ Там же.

${ }^{67}$ Петр из Младоневиц. Донесение о магистре Яне Гусе в Констанце... - I. 2. - С. 19.

${ }_{68}^{68}$ Вертеловский А. История гуситов (до утверждения Базельских компактатов) // ТКДА. - 1872. - № 9. - C. 102,115 .

69 Лаврентий из Бржезовой. Гуситская хроника... - LIV. - С. 107; LVI. - C. 114.

${ }^{70}$ Вертеловский А. История гуситов (до утверждения Базельских компактатов) // ТКДА. - 1873. - № 8. - C. 221 .

${ }^{71}$ Мацек Й. Гуситское революционное движение / Пер. с чеш. Н.М. Пашевой. - М.: Изд-во иностранной лит-ры, 1954. - С. 57.

${ }_{72}$ Кочубинский А. Братья подобои и чешские католики в начале XVII века. - Одесса: Тип. Ульриха и Шульца, 1873. - С. I, II, 2.

${ }_{73}^{73}$ Иванцов-Платонов А. Очерк истории христианства у славянских народов... - С. 686, 687.

${ }^{74}$ Кочубинский А. Братья подобои и чешские католики... - С. 128.

${ }^{75}$ Флоря Б.Н. Россия и чешское восстание против Габсбургов. - М.: Наука, 1986. - С. 93.

${ }^{76}$ Кочубинский $A$. Братья подобои и чешские католики в начале XVII века... - C. 2.

${ }_{77}$ Славяноведение в дореволюционной России: Биобиблиографический словарь... - С. 196.

78 Лаптева Л.П. Чешская феодальная история в освещении русской историографии XIX - начала XX века // Вопросы истории славян. - Воронеж, 2001. - Вып. 15. - С. 128.

${ }^{79}$ Кочубинский А. Братья подобои и чешские католики... - С. 35.

${ }^{80}$ Там же. - С. 40.

${ }^{81}$ Сикст из Оттерсдорфа. Хроника событий, свершившихся в Чехии в бурный 1547 год / Пер. с чешск. и коммент. А.И. Виноградовой и Г.П. Мельникова. - М.: Наука, 1989. - С. 106-109.

${ }^{82}$ Кочубинский $A$. Братья подобои и чешские католики... - С. 100, 113.

${ }^{83}$ Там же. - C. 168.

${ }^{84}$ Там же. - C. 171. 
${ }^{85}$ Там же. - С. 257.

${ }^{86}$ Там же. - С. 344.

87 Флоря Б.Н. Россия и чешское восстание против Габсбургов...- С. 3, 91.

${ }^{88}$ Будилович А.C. О Яне Непомуцком, иезуитско-габсбургском святом. Отдельный оттиск // Волынские епархиальные ведомости. - 1879. - № 16. - С. 3.

${ }^{89}$ Там же. - C. $17-18$.

${ }_{90}$ Будилович А.С. Очерки из церковной истории западных славян. Несколько критических замечаний на латинскую легенду о пражском епископе Войтехе (St. Adalbertus). - Варшава: В тип. Варшавского учебного округа, 1880. - С. 10.

${ }^{91}$ Там же. - С. 27.

92 Там же. - C. 28.

${ }_{93}^{93}$ Там же. - C. 55.

${ }^{94}$ Там же. - C. 146, 148.

${ }^{95}$ Там же. - С. 192.

${ }_{96}$ Леонтович Ф.И. Рец. на: Успенский Ф.И. Первые славянские монархии на Северо-Западе. СПб., 1872) // ЖМНП. - 1876. - № 2. - С. 443.

${ }_{97}$ См.: Регель B.Э. Учредительные грамоты Пражской епархии // Сборник статей по славяноведению, составленный и изданный учениками В.И. Ламанского. - СПб., 1883. - С. 265-330.

${ }_{98}^{9}$ Галл Аноним. Хроника и деяния князей или правителей польских / Предисл., пер. и примеч. Л.М. Поповой. - М.: Изд-во АН СССР, 1961. - І. 6. - С. 33.

${ }_{99}$ Козьма Пражский. Чешская хроника / Вступ. ст., пер. и коммент. Г.Э. Санчука. - М.: Изд-во AH CCCP, 1962. - I. 28-29. - C. 70-72; I. 31. - C. 75.

${ }^{100}$ Сперанский М.Н. Гуситы и чешские братья // Книга для чтения по истории средних веков / Под ред. П.Н. Виноградова. - М., 1903. - Вып. 4. - С. 117-127. 